\title{
WWC1 wt Allele
}

National Cancer Institute

\section{Source}

National Cancer Institute. WWC1 wt Allele. NCI Thesaurus. Code C125168.

Human WWC1 wild-type allele is located in the vicinity of $5 q 34$ and is approximately 181 $\mathrm{kb}$ in length. This allele, which encodes protein KIBRA, is involved in the hippo signaling pathway and as a transcriptional coactivator for estrogen receptor. 